LWSA

Local Wisdom, Social, and Arts

PAPER - OPEN ACCESS

\title{
Penyelesaian Perkara Pidana Anak Melalui Diversi sebagai Bentuk Perlindungan Bagi Anak
}

\author{
Author : Nurmalawaty Nurmalawaty \\ DOI $\quad: 10.32734 /$ lwsa.v1i1.146 \\ Electronic ISSN : :2654-7058 \\ Print ISSN : 2654-7066
}

Volume 1 Issue 1 - 2018 TALENTA Conference Series: Local Wisdom, Social and Arts

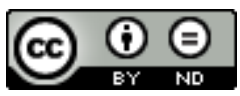

This work is licensed under a Creative Commons Attribution-NoDerivatives 4.0 International License.

Published under licence by TALENTA Publisher, Universitas Sumatera Utara
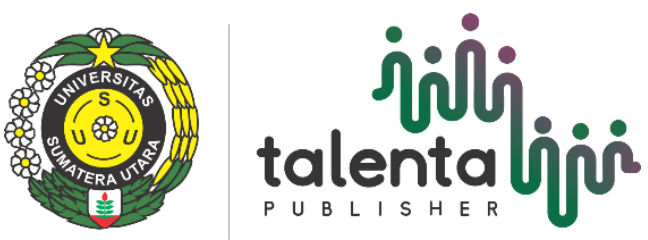


\title{
Penyelesaian Perkara Pidana Anak Melalui Diversi sebagai Bentuk Perlindungan Bagi Anak
}

\author{
Nurmalawaty $^{\mathrm{a}}$ \\ Fakultas Hukum, Universitas Sumatera Utara, Medan-20155 \\ nurmalawaty@rocketmail.com
}

\begin{abstract}
Abstrak
Ide Diversi pada awalnya dicanangkan dalam United Nation Standard Minimum Rules for the Administration of Juvenile Justice atau dikenal dengan The Beijing Rules. Diversi merupakan pemberian kewenangan kepada aparat penegak hukum untuk mengambil tindakan / kebijaksanaan dalam menangani atau menyelesaikan masalah pelanggar anak dengan tidak mengambil jalan formal, misalnya dengan menghentikan atau tidak meneruskan/melepaskan dari proses peradilan pidana. Dengan diundangkan Undang-undang Nomor 11 tahun 2012 tentang Sistem Peradilan Pidana Anak pada tanggal 30 Juli 2012, dan mulai berlaku 2 (dua) tahun kemudian, maka Indonesia secara sah sudah memiliki suatu peraturan yang memberikan perlindungan hukum terhadap anak yang berhadapan dengan hukum dengan salah satu metodenya adalah Diversi. Selanjutnya sebagai Peraturan Pelaksana dikeluarkannya Perma Nomor 4 tahun 2014 tentang Pedoman Pelaksanaan Diversi Dalam Sistem Peradilan Anak, dan Peraturan Pemerintah Nomor 65 tahun 2015 tantang Pedoman Pelaksanaan Diversi dan Penanganan Anak yang Belum Berumur 12 (dua belas) tahun. Pada prinsipnya Diversi dengan pendekatan keadilan restoratif untuk memberikan jaminan perlindungan hukum terhadap anak yang berhadapan dengan hukum untuk menghindari stigmatisasi terhadap anak serta diharapkan anak dapat kembali ke dalam lingkungan social secara wajar. Keadilan Restoratif adalah suatu proses dimana semua pihak yang terlibat dalam suatu perkara pidana bersama-sama menyelesaikan masalah serta menciptakan suatu kewajaran untuk membuat segala sesuatunya menjadi lebih baik dengan melibatkan korban, anak dan masyarakat dalam upaya mencari solusi memperbaiki dan menentramkan hati dengan tidak berdasaarkan pembalasan.
\end{abstract}

Kata Kunci: perkara pidana anak; diversi; perlindungan anak

\section{Pendahuluan}

Perkembangan pembangunan yang cepat, arus globalisasi di bidang komunikasi dan informasi, kemajuan ilmu pengetahuan dan teknologi, serta perubahan gaya dan cara hidup sebagian orang tua yang telah membawa perubahan sosial yang mendasar dalam kehidupan masyarakat yang sangat berpengaruh terhadap nilai dan perilaku anak. Penyimpangan tingkah laku atau perbuatan melanggar hukum yang dilakukan oleh anak, antara lain disebabkan oleh faktor di luar diri anak tersebut. Kenakalan anak setiap tahun selalu meningkat, apabila dicermati perkembangan tindak pidana yang dilakukan anak selama ini, baik dari kualitas maupun modus operandi yang dilakukan, kadangkadang tindakan pelanggaran yang dilakukan anak dirasakan meresahkan semua pihak khususnya orang tua.

Meningkatnya perilaku tindak kekerasan yang dilakukan anak seolah-olah tidak sebanding lurus dengan usia pelaku. Oleh karena itu, berbagai upaya pencegahan dan penanggulangan kenakalan anak perlu segera dilakukan. Salah satu pencegahan dan penanggulangan kenakalan anak saat ini adalah melalui penyelanggaran system peradilan anak. Tujuan penyelenggaraan sistem peradilan anak tidak semata bertujuan untuk menjatuhkan sanksi pidana bagi anak yang telah melakukan tindak pidana, tetapi lebih difokuskan pada dasar pemikiran bahwa penjatuhan sanksi 
tersebut sebagai sarana mendukung mewujudkan kesejahteraan anak pelaku tindak pidana ( Angger Sigit Pramukti, $2015: 2)$.

\section{Pengertian diversi}

Menurut sejarah perkembangan hukum pidana kata - diversion\| pertama kali dikemukakan sebagai kosa kata pada laporan pelaksanaan peradilan anak yang disampaikan Presiden Komisi Pidana (President"s Crime Commission) Australia di Amerika Serikat pada tahun 1960. Pengertian diversi terdapat banyak perbedaan sesuai dengan praktek pelaksanaannya. Konsep diversi didasarkan pada kenyataan bahwa proses peradilan pidana terhadap anak pelaku tindak pidana melalui system peradilan pidana lebih banyak menimbulkan bahaya daripada kebaikan. Alasan dasarnya yaitu pengadilan akan memberikan stigmatisasi terhadap anak atas tindakan yang dilakukan nya seperti anak dianggap jahat, sehingga lebih baik untuk menghindarkannya ke luar system peradilan pidana. ( Marlina, 2010:10-11)

Menurut Levine konsep diversi dimulai dengan pendiriran peradilan anak pada abad ke-19 yang bertujuan untuk mengeluarkan anak dari proses peradilan orang dewasa agar anak tidak lagi diperlakukan sama dengan orang dewasa. Prinsip utama pelaksanaan konsep diversi yaitu tindakan persuasive atau pendekatan non penal dan memberikan kesempatan kepada seseorang untuk memperbaiki kesalahan. Diversi sebagai usaha mengajak masyarakat untuk taat dan menegakkan hukum Negara, pelaksanaannya tetap mempertimbangkan rasa keadilan sebagai prioritas utama disamping pemberian kesempatan kepada pelaku untuk menempuh jalur non-pidana sebagai ganti rugi, kerja social atau pengawasan orang tuanya. Diversi tidak bertujuan mengabaikan hukum dan keadilan sama sekali, akan tetapi berusaha memakai unsur pemaksaan seminimal mungkin untuk membuat orang mentaati hukum. Diversi dilakukan dengan alasan untuk memberikan suatu kesempatan kepada pelanggar hukum agar menjadi orang yang baik kembali melalui jalur non formal dengan melibatkan sumber daya masyarakat. Diversi berupaya memberikan keadilan kepada kasus anak yang telah terlanjur melakukan tindak pidana sampai kepada aparat penegak hukum sebagai pihak penegak hukum. (Marlina, $2010: 13 \neg 15$ )

Secara konseptual, diversi adalah suatu mekanisme yang memungkinkan anak dialihkan dari proses peradilan menuju proses pelayanan social. Dengan demikian, diversi juga bermakna suatu upaya untuk mengalihkan anak dari proses yustisial menuju proses non-yustisial. Upaya untuk mengalihkan proses peradilan (pidana) anak menuju proses non-peradilan didasarkan atas pertimbangan bahwa keterlibatan anak dalam proses peradilan pada dasarnya telah melahirkan stigmatisasi. Berbagai dampak negative akibat anak bersentuhan dengan dunia peradilan menjadi pertimbangan utama dimungkinkannya diversi terhadap penyelesaian kejahatan yang dilakukan oleh anak. Bagaimanapun harus tetap dicatat, bahwa peradilan anak adalah juga merupakan upaya untuk mewujudkan kesejahteraan anak, sehingga pelaksanaannya harus sejauh mungkin menghindarkan anak dari setiap pemidanaan yang bersifat punitive. ( Koesno Adi, $2014: 122$ )

\section{Sistem peradilan pidana anak}

Lahirnya Undang-Undang Republik Indonesia Nomor11 Tahun 2012 tentang Sistem Peradilan Pidana Anak ( selanjutnya disebut UU SPPA ), merupakan sebuah jawaban atas kebutuhan masyarakat dan pemerintah akan peraturan yang memberikan perlindungan bagi anak, khususnya anak yang berhadapan dengan hukum. Dalam undang-undang yang baru ini terdapat banyak perubahan-perubahan, yang paling mencolok adalah diterapkannya proses diversi dalam penyelesaian perkara anak, serta pendekatan Keadilan Restoratif yang melibatkan seluruh Stake Holder terutama masyarakat dalam membantu proses pemulihan keadaan menjadi lebih baik.

Keadilan restoratif ini menjadi penegasan bahwa anak yang berkonflik dengan hukum bukan untuk dihukum, melainkan harus dibimbing dan dibina agar dapat kembali menjadi baik, karena tujuan utama keadilan restoratif adalah mengembalikan kepada kondisi semula dan memberikan penanaman tanggungjawab kepada anak. Anak bukan untuk dihukum adalah sebuah upaya pemenuhan dan perlindungan hak-hak anak Indonesia sebagaimana terdapat dalam UUD 1945, Konvensi Hak Anak, UU HAM maupun UU Perlindungan Anak.( M.Nasir, 2013 : xi ). 
Dalam UU SPPA keadilan Restoratif diartikan sebagai penyelesaian perkara tindak pidana dengan melibatkan pelaku, korban, keluarga pelaku/korban, dan pihak lain yang terkait untuk bersama-sama mencari penyelesaian yang adil dengan menekankan pemulihan kembali pada keadaan semula, dan bukan pembalasan ( Pasal 1 angaka 6 ). Berdasarkan pengertian di atas dapat dikatakan bahwa keadilan restroatif merupakan teori keadilan yang menekankan pada pemulihan kerugian yang disebabkan oleh perbuatan pidana. Penyelesaian dianggap paling baik dengan mempertemukan para pihak secara koperatif untuk memutuskan bagaimana menyelesaikan masalah.( Yutirsa Yunus, $2013: 233$ )

Dasar pemikiran pembentukan Undang-Undang tentang Sistem Peradilan Pidana Anak harus disertakan dasardasar filosofis, yuridis, dan sosiologis. Dalam Naskah Akademik RUU Sistem Peradilan Pidana Anak, disebutkan dasar-dasar pemikiran dalam pembentukan RUU tersebut, antara lain: ( M.Nasir, $2013: 51$ )

Pertama, Dasar Filosofis. Dasar filosofis adalah pandangan hidup bangsa Indoneisa dalam berbangsa dan bernegaram yaitu pancasila. Penjabaran nila-nilai pancasila di dalam mencerminkan suatu keadilan, ketertiban, dan kesejahteraan yang diinginkan oleh masyarakat Indonesia. Disebutkan bahwa anak merupakan amanah dan karunia Tuhan Yang Maha Esa yang memiliki harkat dan martabat sebagai manusia seutuhnya, sehingga untuk menjaga harkat dan martabatn ya, anak berhak mendapat perlidungan khusus, terutama perlindungan hokum dalam system peradilan anak. Dasar filosofis ini mengafirmasi nilai-nilai pancasilayakni ketuhanan yang maha esa, dan kemanusiaan yang adil dan beradab, sehingga bangsa yang bermartabat dan menjunjung tinggi nilai-nilai religiusitas, maka permasalahan anak yang berhadapan dengan hokum harus diberikan prioritas yang terbaik bagi anak.

Kedua, Dasar Sosiologis. Tindak pidana anak dewasa ini secara kuantitas dan kualitas cenderung meningkat dibandingkan tindak pidana lain, nyaris semua tindak pidana yang dilakukan orang dewasa dilakukan pula oleh anak-anak. Undang-undang tentang Sistem Peradilan Pidana Anak dimaksudkan untuk melindungi dan mengayomi anak yang berhadapan dengan hukum agar dapat menyongsong masa depannya yang masih panjang serta member kesempatan kepada anak agar melalui pembinaan akan diperoleh jati dirinya untuk menjadi manusia yang mandiri, bertanggungjawab, dan berguna bagi diri sendiri, keluarga, masyarakat, bangsa dan Negara.

Ketiga, Dasar Yuridis. Menurut teori, hukum haruslah membantu manusia berkembang sesuai dengan kodratnya; ,menjunjung keluhuran martabat manusia, bersifat adil, menjamin kesamaan dan kebebasan, memajukan kepentingan dan kesejahteraan umum. Perlindungan hukum terhadap anak harus sesuai dengan Konvensi Hak-Hak Anak (Convention on the Rights of the Child) sebagaimana telah diratifikasi oleh Pemerintah Republik Indonesia dengan Keputusan Presiden Nomor 36 Tahun 1990.

Keempat, Dasar Psikopolitik Masyarakat. Psikopolitik masyarakat adalah suatu kondisi nyata di dalam masyarakat mengenai tingkat penerimaan (acceptance) atau tingkat penolakan (resistance) terhadap suatu peraturan perundang-undangan. Tindak pidana yang dilakukan anak baik langsung maupun tidak langsung merupakan suatu akibat dari perbuatan dan tindakan yang dilakukan orang dewasa dalam bersinggungan dengan anak atau merupakan sebagai bagian dalam proses interaksi anak dengan lingkungannya, di mana anak belum mampu secara dewasa menyikapinya. Paradigma ini yang harus ditanamkan bagi masyarakat dan aparatur penegak hukum dalam menghadapi anak yang diduga melakukan suatu tindak pidana.

Dengan demikian dapat dikatakan bahwa Sistem Peradilan Pidana anak akan mengutamakan perlindungan dan rehabilitasi terhadap pelaku anak (emphasized the rehabilitation of youthful offender) sebagai orang yang masih mempunyai sejumlah keterbatasan dibandingkan dengan orang dewasa. Anak memerlukan perlindungan dari Negara dan masyarakat dalam jangka waktu ke depan yang masih panjang. Terhadap anak yang terlanjur menjadi pelaku tindak pidana diperlukan strategi system peradilan pidana yaitu mengupayakan seminimal mungkin intervensi system peradilan pidana.

\section{Pelaksanaan diversi dalam peradilan anak}

Penegakan hukum merupakan bagian sangat penting dibicarakan bila ingin menjawab bagaimana diversi dapat memberikan jaminan penegakan hukum bagi masyarakat baik korban, pelaku, dan masyarakat. Penegakan hukum berfungsi sebagai perlindungan kepentingan manusia. Masyarakat tidak hanya menjadi objek dari hukum tetapi berperan aktif dalam penegakan hukum. Penerapan prinsip diversi merupakan pengarahan penggunaan hak diskresi 
oleh petugas untuk mengurangi kekuatan hukum pidana dalam menangani perkara terutama perkara anak. Oleh karena itu untuk menjalankan diversi diperlukan aturan dan cara pelaksanaan yang benar-benar dibangun agar dapat menajdi sisi lain dari penegakan hukum yang tepat pada masyarakat.

Perlindungan hukum bagi anak dapat diartikan sebagai upaya perlindungan hukum terhadap berbagai kebebasan dan hak asasi anak (fundamental rights and freedom of children) serta berbagai kepentingan yang berhubungan dengan kesejahteraan anak. Jadi masalah perlindungan hukum bagi anak mencakup lingkup yang sangat luas. Lingkup perlindungan hukum bagi anak-anak mencakup : (1) Perlindungan terhadap kebebasan anak; (2) Perlindungan terhadap hak asasi anak ; dan (3) Perlindungan hukum terhadap semua kepentingan anak yang berkaitan dengan kesejahteraan.( Waluyadi, $2009: 1$ )

Secara teoritis, (Koesno Adi, 2014 : 123) penyelesaian perkara anak melalui mekanisme diversi akan memberikan berbagai manfaat : Memperbaiki kondisi anak demi masa depannya, meningkatkan peran serta masyarakat dalam rangka perlindungan anak, meningkatkan peran dan kesadaran orang tua dan lingkungan keluarga anak, dan mengurangi beban kerja pengadilan.

Dalam Pasal 6 Undang-Undang Republik Indonesia Nomor11 Tahun 2012 tentang Sistem Peradilan Pidana Anak, disebutkan diversi bertujuan : Mencapai perdamaian antara korban dan Anak, menyelesaikan perkara anak di luar proses peradilan, menghindarkan anak dari perampasan kemerdekaan, mendorong masyarakat untuk berpartisipasi, dan menanamkan rasa tanggung jawab kepada anak.

Berbagai manfaat tersebut di atas pengalihan proses yustisial ke proses non-yustisial dalam penyelesaian perkara anak mempunyai urgensi dan relevansi sebagai berikut:

Pertama, proses penyelesaian yang bersifat non-yustisial terhadap anak akan menghindarkan terjadinya kekerasan terpola dan sistematis, khususnya kekerasan psikologis terhadap anak oleh aparat penegak hukum. Terjadinya kekerasan terpola dan sistematis terhadap anak dalam proses pemeriksaan akan menimbulkan trauma yang sangat mendalam bagi anak. Oleh karenanya, penyelesaian yang bersifat non-yustisial melalui mekanisme diversi terhadap anak justru akan menghindarkan anak dari dampak negative karena terjadinya kontak antara anak dengan aparat penegak hukum dalam proses peradilan. Kedua, melalui mekanisme diversi anak tetap diberikan peluang untuk mempertanggungjawabkan perbuatannya, tetapi melalui mekanisme yang lebih elegan menurut perspektif anak. Penyelesaian secara non-yustisial tidak dimaksudkan untuk membebaskan anak dari kemungkinan adanya pertanggungjawaban anak terhadap segala akibat perbuatannya. Oleh karenanya, melalui mekanisme diversi akan diperoleh keuntungan ganda. Di satu sisi anak terhindar dari berbagai dampak negative akibat kontak dengan aparat penegak hukum, sementara di sisi lain anak tetap dapat mempertanggungjawabkan akibat perbuatannya tanpa harus menjadi tekanan terhadap mental anak.

Ketiga, mekanisme diversi dapat dianggap sebagai mekanisme koreksi terhadap penyelenggaraan peradilan terhadap anak yang berlangsung selama ini. Mekansime formal yang ditonjolkan dalam proses peradilan pidana termasuk terhadap anak sering menimbulkan dampak negative yang demikian kompleks, sehingga menjadi factor kriminogen yang sangat potensial terhadap tindak pidana anak.

Keempat, sebagai pengalihan proses yustisial ke non-yustisial, diversi berorientasi pada upaya untuk memberikan pelayanan social kepada pelaku kejahatan, tetapi lebih dipandang sebagai korban yang membutuhkan berbagai layanan seperti, medis, psikologi, rohani. Oleh karena sifatnya yang demikian maka diversi hakekatnya merupakan upaya untuk menghindarkan anak dari kemungkinan penjatuhan pidana. Dengan demikian, diversi juga merupakan proses depenalisasi dan sekaligus dekriminalisasi terhadap pelaku anak.

Diversi pada hakikatnya juga mempunyai tujuan agar anak terhindar dari dampak negative penerapan pidana. Diversi juga mempunyai esensi tetap menjamin anak tumbuh dan berkembang baik secara fisik maupun mental. Dengan demikian, maka juga dapat dikatakan, bahwa pada dasarnya diversi mempunyai relevansi dengan tujuan pemidanaan terhadap anak. Relevansi antara diversi dengan tujuan pemidanaan bagi anak nampak dalam hal-hal sebagai berikut: Pertama, diversi sebagai pengalihan proses dari proses yustisial menunju proses non-yustisial yang bertujuan menhindarkan anak dari penerapan hukum pidana yang seringkali memberikan pengalaman yang pahit berupa stigmatisasi berkepanjangan, dehumanisasi dan menghindarkan anak dari kemungkinan terjadinya prisonisasi yang menjadi sarana transfer kejahatan terhadap anak. Demikian juga tujuan pemidanaan bagi anak adalah untuk tetap memberikan jaminan kepada anak agar tumbuh dan berkembang baik secara fisik maupun secara mental. Kedua, Perampasan kemerdekaan terhadap anak, baik dalam bentuk pidana penjara maupun dalam bentuk 
perampasan yang lain melalui mekanisme peradilan pidana memberikan pengalaman yang traumatis terhadap anak, sehingga anak terganggu perkembangan dan pertumbuhan jiwabnya. Pengalaman pahit bersentuhan dengan dunia peradilan akan menjadi bayang-bayang gelap kehidupan anak yang tidak mudah untuk dilupakan.

Walaupun diversi sudah mulai dikenal sebagai upaya penanganan anak di luar proses peradilan, tetapi masih terdapat beberapa hambatan dalam pelaksanaannya, antara lain :

Pertama, Subtansi Hukum. Adanya kelemahan UU SPPA, antara lain Pasal 105 yang memberikan jangka waktu paling lama 5 (lima) tahun setelah diundangkannya agar kementrian yang menyelenggarakan urusan pemerintahan di bidang hukum wajib membangun BAPAS ( Balai Pemasyarakatan), LPKA ( Lembaga Pembinaan Khusus Anak), LPAS (Lembaga Penempatan Anak Sementara), LPKS (Lembaga Penyelenggaraan Kesejahteraan Sosial) di tiap propinsi. Namun UU ini tidak memberikan apakah ada implikasi hukum kepeda pemerintah atau lembaga Negara lainnya jika memenuhi apa yang diamanatkan oleh UU tersebut.

Selain hal tersebut di atas, dalam Pasal 7 ayat (2) huruf a UU SPPA ditentukan bahwa "diversi dilaksanakan dalam hal tindak pidana yang dilakukan diancam dengan pidana penjara di bawah 7 (tujuh) tahun $\|$, sementara dalam Pasal 3 Perma RI Nomor 4 tahun 2014 ditentukan bahwa " Hakim wajib mengupayakan diversi dalam hal anak didakwa melakukan tindak pidana yang diancam dengan pidana penjara di bawah 7 (tujuh) tahun dan didakwa dengan tindak pidana yang diancam dengan tindak pidana penjara 7 (tujuh) tahun atau lebih dalam bentuk surat dakwaan subsidaritas, alternative, kumulatif maupun kombinasi (gabungan). Terhadap ketentuan Perma ini dapat dikatakan bertentangan dan lebih luas pengaturannya dengan UU SPPA.

Kedua, Struktur Hukum. Struktur hukum ( legal structur) adalah pola yang memperlihatkan tentang bagaimana hukum itu dijalankan menurut ketentuan-ketentuan formalnya, bagaiman peradilan, pembuatan hukum serat proses hukum itu berjalan dan dijalankan. Berjalannya fungsi institusi ditentukan oleh setiap petugas yang menjalankan fungsi kelembagaan tersebut. ( Satjipto Raharjo, 2006 : 154 ). Dalam kaitan ini masih terbatasnya sumber daya / kemampuan aparat penegak hukum baik dari segi kuantitas maupun dari segi kualitas sehingga hal ini menjadi penghambat kinerja institusi. Hal ini dapat diketahui masih tingginya kasus-kasus anak yang diproses baik pada tingkat penyidikan, penuntutan dan di depan pengadilan.

Ketiga, Kultur Hukum. Dalam Pasal 9 ayat (2) UU SPPA menyebutkan bahwa kesepakatan diversi harus mendapat persetujuan korban dan/atau keluarga korban serta kesediaan anak dan/atau kelurganya, sehingga dalam hal ini yang menjadi tolak ukurnya adalah adanya perdamaian antara korban dan anak. Dalam proses diversi tidak jarang masyarakat menjadi penghambat, karena kelurga korban yang tidak mau untuk dilakukan diversi maupun tidak mau berdamai dengan anak dan hanya mau anak tersebut dihukum oleh pengadilan, ataupun jika mau berdamai meminta ganti rugi yang sangat besat yang tidak mapu dipenuhi oleh anak. Kondisi ini semakin diperparah karena lingkungan sekitar keluarga korban mendukung untuk itu sehingga kemungkinan diversi semakin kecil.

\section{Kesimpulan}

Dengan lahirnya UU SPPA sebagai peraturan khusus yang mengatur hukum acara peradilan anak dengan menghadirkan konsep diversi dan pendekatan restorative justice memberikan tujuan agar menghindarkan anak dari sistem retributive yang selama ini menimbulkan efek yang kurang baik bagi si anak, sehingga dengan konsep tersebut akan memberikan pemulihan terhadap anak dan akibat yang dilakukannya. Dalam pelaksanaannya, penyelesaian perkara pidana anak dalam praktik mengalami kendala, baik dari substansi hukum, struktur hukum maupun budaya hukumnya. 


\section{Daftar pustaka}

[1] Adi, Koesno (2015), Diversi Tindak Pidana Narkotika Anak, Malang, Setara Press, hal 122-14

[2] Djamil, Nasir M (2013), Anak Bukan Untuk Dihukum, Jakarta, Sinar Grafika, hal xi, 51-54

[3] Marlina (2010), Pengantar Konsep Diversi dan Restoratif Justice Dalam Hukum Pidana, Medan, USU Press, hal 10-16

[4] Pramukti, Anggar Sigit (2015), Sistem Peradilan Pidana Anak, Yogyakarta, Pustaka Yustisia, hal 1-3

[5] Rahardjo, Satjipto (2006), Ilmu Hukum, Bandung, Citra Aditya Bakti, hal 154

[6] Waluyudi (2009), Hukum Perlindungan Anak, Bandung, Mandar Maju, hal 1

[7] Yunus, Yutirsa ( 2013), Analisis Konsep Retoratif Justice Melalui Sistem Diversi dlam Sistem Peradilan Pidana Anak, Jurnal Rechtsvinding, Volume 2 Nomor 2, Agustus, hal 233 